The Utility of Nymphaeaceae Sclereids in Paleoenvironmental Research

by

Robby R. Marrotte

A Thesis Submitted in Partial Fulfillment of the Requirement for the Degree of B. Sc. Honours in Geography

\author{
Department of Geography \\ McGill University \\ Montréal (Québec) Canada
}

May 2011

(C) 2011 Marrotte 


\section{The Utility of Nymphaeaceae Sclereids in Paleoenvironmental Research}

Robby R. Marrotte

Department of Geography, McGill University; Montréal (Québec) Canada

2011

Supervisor: Gail L. Chmura

Reader: Elisabeth Levac

As entomophilous plants, water lilies (Nymphaea) and spatterdocks (Nuphar) have low pollen production, thus can be under represented in the sediment record. These macrophytes produce distinctly shaped sclerenchyma tissue referred to as stone-cells, trichosclereids, astrosclereid or simply sclereids. This study examines the utility of using sclereids from common species from the Nymphaeaceae Family as an alternative proxy to their pollen. Histological studies of fresh tissues of Nymphaea odorata and Nuphar lutea revealed that each has distinct sclereids and that there has been confusion in the application of terminological used to designate their morphology. Some paleoecological reports have referred to Nymphaeaceae sclereids as trichosclereids, but our histological studies show that the cells are more appropriately classified as polyramous, astrosclereids, librosclereids and rhizosclereids. We also determined if palynological processing affects sclereid morphology or the efficiency of their retrieval. Tissues from both species were treated using $\mathrm{HCL}, \mathrm{KOH}$, acetolysis and $\mathrm{HF}$ and found that only the sclereids from $N$. lutea survived chemical treatments in a detectable form. Our study shows that sclereids from $N$. lutea can be a useful indicator of its presence while the chance of observing sclereids from $N$. odorata in pollen preparations is very low, severely limiting the utility of the latter as a paleoecological indicator. Another limitation to using sclereids as a proxy is that they originate from plant tissues, which require extended acetolysis treatments for; if they aren't released from this matrix they stay hidden inside the tissue. Thus extended acetolysis treatments may be required to release sclereids from peat. Finally, we examined sclereid abundance in sediments from a slough in the Florida Everglades to determine if abundance of Nymphaeaceae sclereids correlates with Nymphaeaceae pollen and we find no significant correlation. Additional analyses are required to determine if empirical relationships exist amongst plant populations, pollen, sclereids and environmental conditions. A clear report of chemical treatments used and processing times are critical to verify results of studies utilizing sclereids. 


\section{Introduction}

As entomophilous plants, water lilies (Nymphaea) and spatterdocks (Nuphar) have low pollen production (Faegri and Iversen, 1989), thus can be under represented in the sediment record (Warner, 1989). This makes the reconstruction of wetlands problematic, since aquatic macrophytes are common in these environments. However, the tissue remains of these plants can be used to reconstruct their abundance through time. In addition, some macrophytes produce sclerenchyma tissue resistant to natural decay, named sclereids (Tschirch, 1889), which can be identified to the correct taxa (Rao and Banerjee, 1979). Of these, members of the water lily or Nymphaeaceae family produce distinctly shaped sclerenchyma tissue referred to as stone-cells (Warner, 1989), trichosclereids (Davidson et al., 2005, Kuhry, 1997, Miola et al., 2006, Pals et al., 1980, Pokorný et al., 2000, Ralska-Jasiewiczowa et al., 1992, Rikke et al., 2007, Shuman et al., 2009), astrosclereid (Eide et al., 2006) or simply sclereids (Arsenault et al., 2007, Warner, 1989). After searching three bibliographic databases it was found that the use of sclereids in paleoecology has not been carefully reviewed nor tested. This study examines the utility of using sclereids from Nuphar lutea and Nymphaea odorata as an alternative proxy for their pollen.

Nymphaeaceae sclereids appear as isolated cells which differ from neighbouring plant tissues, signifying they are easily distinguished from other cells by their size, shape and thickness of their wall (Fahn, 1974). They are composed of complex polymers of lignin, cellulose (Warner, 1989) and impregnated by calcium oxalate crystals (Bercu, 2003, Ogden, 1974). In the Nymphaeaceae family, sclereids are contained in the petioles, peduncles and leaves, where they act as branched support cells (Gaudet, 1960, Ogden, 1974)- possibly functioning as reinforcements for aerenchyma channels in the leaf and stem (Brodribb et al., 2010). Some 
propose that sclereids cause the plant tissue to be coarse and gritty making it less favourable for consumption by herbivores or insects, suggesting an adaptation against herbivores (Bercu, 2003, Mauseth, 1988).

Our understanding of the ontogeny and distribution of sclereids within plants has evolved since the early work by Tschirch who categorized sclereids by their shape into 4 groups: brachysclereids, macrosclereids, osteosclereids and astrosclereids (Tschirch, 1889). Rao and Bhupal (1973) later adjusted the typology differentiating sclereid groups by their shapes and sizes. Rao and Banerjee (1979) applied the typology of Rao and Bhupal (1973) in a study of foliar sclereids of the Nymphaeaceae family to determine if it was possible to use them for familial classification. They reported that Nuphar leaves have polyramous sclereids (Figure 1: \#39-42) and Nymphaea leaves have fusiform (Figure 2: \#18-21) to polyramous (Figure 1: \#3942) sclereids, while previous studies by Conard (1905) and Malaviya (1962) classified them as astrosclereids (Figure 1: \#30-31) and/or trichosclereids (Figure 1: \#37-38). In a much earlier study, Gaudet (1960) had examined Nymphaea odorata peduncular and petiolar sclereids and described them as "I" or "H" shaped (Figure 3). More recently Bercu (2003) described the sclereids from his specimens of Nuphar lutea and Nymphaea alba as trichosclereids.

The terminology and classification of sclereids has been inconsistently applied in paleoecological studies. Some investigators have called them "sclereids" (Arsenault et al., 2007, Warner, 1984), "astrosclereids" (Eide et al., 2006), or "trichosclereids" (Davidson et al., 2005, Kuhry, 1997, Miola et al., 2006, Pals et al., 1980, Pokorný et al., 2000, Ralska-Jasiewiczowa et al., 1992, Rikke et al., 2007, Shuman et al., 2009). The first paleoecological study I have found that identifies Nymphaeaceae sclereids is by Pals et al. (1980), which was identified as unknown non-pollen palynomorph “Type 129” (Figure 4). Pals et al. (1980) determined that the taxonomic 
affinity of Type 129 was the Nymphaeaceae family and referred to it as a trichosclereid, but do not cite their source. Apparently independently, Warner (1984) later used the term sclereid citing back the source of his classification to a plant anatomy textbook by Ogden (1974) which, was produced before the classification of some of the Nymphaeaceae species by Rao and Benerjee (1979). This may explain why Warner did not classify the sclereids as polyramous or fusiform and may be the reason for the similar treatment by Pals et al. (1980). The limitation of the classification of Rao and Banerjee (1979) to only foliar sclereids has probably added to confusion regarding Nymphaeaceae sclereids and the presence of petiolar and peduncular sclereids was probably overlooked in the past. Thus there is a need to examine the morphology of sclereids in peduncles and petioles as their tissues are as important a contribution to the sedimentary record as leaves.

A search of paleoecological literature in Scopus, ISI and Google Scholar using the terms sclereid, trichosclereid, and astrosclereid, identified 11paleoecological studies that report Nymphaeaceae sclereids (Arsenault et al., 2007, Davidson et al., 2005, Eide et al., 2006, Kuhry, 1997, Miola et al., 2006, Pals et al., 1980, Pokorný et al., 2000, Ralska-Jasiewiczowa et al., 1992, Rikke et al., 2007, Shuman et al., 2009, Warner, 1984), but variably as part of the palynological or macrofossil component (Table 1). Some researchers identified them on their pollen slides (Arsenault et al., 2007, Pals et al., 1980, Pokorný et al., 2000, Ralska-Jasiewiczowa et al., 1992, Shuman et al., 2009, Warner, 1984) and others report them in macrofossil samples (Davidson et al., 2005, Eide et al., 2006, Kuhry, 1997, Miola et al., 2006, Rikke et al., 2007).The size of sclereids, 100-400 $\mu \mathrm{m}$ (Warner, 1989), probably explains their presence in both types of samples as it spans the range targeted in both palynological and macrofossil studies. 
Although recognized and reported, the use and documentation of Nymphaeaceae sclereids are considerably variable. Two studies include no reference for identification and make no interpretation of sclereid abundance (Eide et al., 2006, Rikke et al., 2007). Three studies do provide a reference for their identification, but apparently make no use of sclereids for environmental interpretation (Kuhry, 1997, Miola et al., 2006, Pokorný et al., 2000). Shuman et al. (2009) and Davidson et al. (2005) utilize sclereids for their interpretation, but reference no source for their identification. Of the 11studies reporting Nymphaeaceae sclereids, only four studies both utilize sclereids in their interpretation and provide a reference for their identification (Arsenault et al., 2007, Pals et al., 1980, Ralska-Jasiewiczowa et al., 1992, Warner, 1984). Because of the irregularity of the consideration of Nymphaeaceae sclereids in paleoecological reports, I cannot be certain if the low number of paleoecological studies that include sclereids is due to their rarity in samples, lack of recognition of their morphology, or lack of knowledge of what conditions they indicate.

Those who have reported sclereids have made variable and contradictory interpretations of sclereid abundances. Both Pals et al. (1980) and Shuman et al. (2009) mention that the abundance of Nymphaeaceae trichosclereids corresponds with abundance of Nymphaeaceae pollen, but Pals et al. (1980) show a trend with Nuphar pollen and Shuman et al. (2009) shows a trend with Nymphaea pollen. This would mean that sclereids could be an alternative to the rare Nuphar and Nymphaea pollen as suggested by Warner (1989). However, some have concluded that sclereid abundances are driven by environmental factors, since Nymphaeaceae species grow in specific aquatic environments. Pokorný et al. (2000) concluded that the presence of trichosclereids indicated the presence of permanent water bodies. Ralska-Jasiewiczowa et al. (1992) associated the increased abundance of trichosclereids to a rise in temperature of a lake in 
central Poland. Arsenault et al. (2007) assumed that increased abundance of sclereids indicated increased nutrient concentrations associated with decreased water levels, with the confirmation of other indicators, such as sediment lithology were necessary. Rikke et al. (2007) suggested that increases in trichosclereid indicated the colonization of flooded areas.

Chemical treatments and sieving could affect the retrieval and recognition of sclereids. These paleoecological studies which have included sclereids in their study have also used different techniques to concentrate their fossils (Table 1). Six of these studies cite techniques from the textbook by Faegri and Iversen (1989 and 1975), Davidson et al. (2005) cites techniques from the textbook by Moore et al. (1991), Pokorný et al., (2000) cites both textbooks and Kuhry (1997) does not reference his techniques, but does describe them. Of the 6 studies which have found sclereids on their pollen slides, one study does not give any details on the chemicals used to concentrate their pollen samples (Shuman et al., 2009) and only 2 mention that they sieved their samples (Arsenault et al., 2007, Warner, 1984). Of the 5 studies which have found sclereids in their macrofossil samples, 2 studies do not mention chemicals used to process their samples (Davidson et al., 2005, Rikke et al., 2007). Acetolysis, regularly used to concentrate pollen, dissolves cellulose and lignin (Hesse and Waha, 1989) and sclereids are composed of complex lignin and cellulose polymers. Yet, 6 studies utilized acetolysis and sclereids were still visible on their pollen slides (Arsenault et al., 2007, Pals et al., 1980, Pokorný et al., 2000, Ralska-Jasiewiczowa et al., 1992, Shuman et al., 2009, Warner, 1984) or within their macrofossil samples (Davidson et al., 2005, Eide et al., 2006, Kuhry, 1997, Miola et al., 2006, Rikke et al., 2007). Some researchers employ acetolysis for extended periods (Willard et al., 2004), which could degrade sclereids beyond recognition, and this may explain the low number 
of studies reporting them. Additonnaly the size of these sclereids could exclude them from pollen slides.

In this study I attempt to isolate some of the factors that have complicated the use and interpretation of Nymphaeaceae sclereids. First I utilize fresh tissue of two common species, Nuphar lutea and Nymphaea odorata, that are found across North America and in many types of habitats (Conard, 1905, Padgett, 2007) and dissect their tissues to determine if their morphology varies between species or within tissue. I hypothesize that sclereids shape does not vary within plant tissues and that sclereids of the two species can be differentiated.

Secondly, I use fresh tissue of these two species to determine if palynological processing affects sclereid morphology or the efficiency of their retrieval, by employing acetolysis treatments of varied duration and comparing sieved and unsieved subsamples. I hypothesize that sieving excludes them from pollen slides and that acetolysis, which is a conventional pollen processing procedure, degrades them to the point where they cannot be differentiated from the organic matter surrounding them.

Finally, I examine sclereid abundance in sediments from a slough in the Florida Everglades to determine if abundance of Nymphaeaceae sclereids correlates with Nymphaeaceae pollen. 


\section{Methods}

Morphology of sclereids

This study utilized both living specimens and sediments known to hold Nymphaeaceae pollen. Fresh tissues of Nuphar lutea and Nymphaea odorata were collected from 2 different areas. Some specimens of $N$. odorata were collected in June from a marsh located near Stanstead, Quebec $\left(45^{\circ} 05^{\prime} 41^{\prime \prime} \mathrm{N}, 72^{\circ} 05^{\prime} 31^{\prime \prime} \mathrm{W}\right)$. Additional specimens of $N$. lutea and $N$. odorata were collected in August from a stream near Opeongo Lake in Algonquin Provincial Park, Ontario $\left(45^{\circ} 38^{\prime} 01^{\prime \prime} \mathrm{N}, 78^{\circ} 21^{\prime} 24^{\prime \prime} \mathrm{W}\right)$. Longitudinal and transversal cross sections were prepared from the peduncle, petiole, and flowers and leaves of all specimens, and examined at 400x magnification. Samples of fresh plant tissues were dried in an oven at $65^{\circ} \mathrm{C}$ until brittle and $2.0 \mathrm{~g}$ of dried tissue was subsampled for the analyses described below.

Sclereid shapes were also examined from dried tissues of both species treated with $10 \%$ $\mathrm{KOH}$ in a hot water bath for $10 \mathrm{~min}$. Prior to this treatment Lycopodium tablets (Stockmarr, 1971) were added to each sample and $\sim 20 \mathrm{ml}$ of $\mathrm{HCl}$ was added to dissolve the tablet. Samples were centrifuged and rinsed with distilled water between chemical treatments. A subsample from the final aliquot was mounted in glycerine jelly on a microscope slide and examined at 400x magnification. Sclereid shape was classified using the typology published by Rao \& Bhupal (1973).

Testing the Effects of palynological processing

The effect of palynological treatment on sclereid morphology was determined using dried subsamples from the peduncle, petiole, and flowers and leaves from N. lutea and N. odorata. 
Prior to other chemical treatments a tablet of Lycopodium marker spores (Stockmarr, 1971) was added to each sample dissolved with $10 \% \mathrm{HCl}$, and rinsed.

The effect of a succesion of chemical treatments was tested using $\sim 20 \mathrm{ml}$ of $\mathrm{KOH}$, glacial acetic acid, acetolysis, $\mathrm{HF}$, and $\mathrm{HCl}$ with centrifugation and distilled water rinses between steps, except where noted. First, samples were treated with a solution of $10 \%$ of $\mathrm{KOH}$ in a hot water bath for $10 \mathrm{~min}$. Samples were dehydrated with glacial acetic acid (use of fresh tissue required careful mixing and 20 min for full dehydration) before proceeding directly with acetolysis (no rinsing). The acetolysis solution was prepared using nine parts acetic anhydride and one part $\mathrm{H}_{2} \mathrm{SO}_{4}$. Samples were placed in a hot water bath for 3 min while being occasionally stirred, decanted and mixed with glacial acetic acid without rinsing (for $10 \mathrm{~min}$ ). Samples were then treated with HF and placed in a hot water bath for 20 min, with occasional stirring. Next samples were treated with $10 \% \mathrm{HCl}$ and placed in a hot water bath and occasionally stirred for $5 \mathrm{~min}$. Samples rinsed with distilled water, stained with Safranin and rinsed again before mounting onto slides using glycerine jelly.

The effect of acetolysis timing alone was investigated by varying the hot water bath duration. About $0.2 \mathrm{~g}$ fresh tissue from each plant part from both species was placed into test tubes. Samples were then held in a hot water for 3, 5 and $10 \mathrm{~min}$, rinsed and mounted using the steps described above.

\section{Testing the Effect of sieve size}

To examine the effect of sieve size on sclereid retrieval, sediment samples known to contain Nymphaeaceae pollen were processed using same techniques described above. Duplicates of each sample were processed with and without sieving at $125 \mu \mathrm{m}$. Sediment were 
subsampled from a core taken from Shark River Slough in the Florida Everglades in the conservation area 3B near Tamiami Trail $\left(25^{\circ} 45^{\prime} 25^{\prime \prime} \mathrm{N}, 80^{\circ} 38^{\prime} 23^{\prime \prime} \mathrm{W}\right)$. Sloughs are the wettest sites in the Everglades and contain floating aquatics such as Nymphaea, Nuphar, and Utricularia (bladderwort). Nearby are marshes vegetated primarily by sawgrass (Cladium), sedges (Cyperaceae) and true grasses such as reed (Phragmites), mannagrasses (Glyceria striata), sloughgrass (Beckmannia syzigachne), and whitetop (Rhynchospora floridensis) (Loveless, 1959). The first layer of the core was composed of a waterlily-Sawgrass peat, followed by a marl layer and the bottom layer was a waterlily-Sawgrass peat. The marl boundaries were dated and this high decomposition episode lasted around 100 years. The sediment core was sectioned following its general lithology and every layer was placed in identified Ziploc bags. The core was $65 \mathrm{~cm}$ long and 8 subsamples of $1 \mathrm{~g}$ of sediment were taken for processing. Two were taken from the top peat layer, 3 from the marl and 3 other from the bottom peat layer (Table 2). Two of the subsamples taken from the marl are located at the peat/marl and marl/peat transition zone, the other was taken from the middle.

\section{Nymphaeaceae sclereid interpretation}

To determine if abundance of sclereids varied with environmental conditions, different paleoenvironments were studied, as interpreted from the lithology of the Shark River Slough sediment core. Two samples were taking from a surface peat layer, 3 from a marl layer and 3 from the lower peat layer. The marl layer spans about $15 \mathrm{~cm}$ of the core. The samples and data used for this part of the research were gathered from the experiment on the effect of sieving, the pollen and sclereid counts from unsieved and sieved samples were added together, since the parametric and nonparametric paired t-test showed no significant change in pollen percentages for each taxa and sclereid between sieving methods. This created a much more reliable pollen 
count for the 8 depths that were analysed. In addition, a surface sample was added to the data, to test for any underrepresented taxa in the pollen counts. The surface sample was conventionally processed and sieved at $125 \mu \mathrm{m}$. To verify if there is any correlation between pollen and sclereid counts, a statistical test was used.

Microscope and statistical analyses

Pollen and plant spores were identified using Kapp et al., 2000, McAndrews et al., 1973, Moore et al., 1991, and Willard et al., 2004, along with reference slides in the McGill paleoenvironmental lab. A minimum of 275 pollen and plant spores were counted in each sample. Only whole Pinus pollen was counted, single bladders were excluded. All shapes of sclereids were categorized and counted. Only sclereids with the longest axis $\geq 50 \mu \mathrm{m}$ were counted. Pollen and sclereid percentages were based on the total pollen sum. Statistical analyses were performed with PASW Statistics (SPSS) for Windows, Release Version 18.0, (SPSS, Inc., 2009). 


\section{Results}

Sclereid morphology

The shape and location of sclereids within plant tissues of the N. lutea specimens collected from Quebec and Ontario were similar and the same star shapes were found throughout the peduncle and petiole tissues (Figure 5A-D). The observation of the foliar sclereids was more challenging, but these sclereids seem star shaped (Figure 5E-F). The size of unfragmented star shaped sclereids from N. lutea ranged from 600-300 $\mu \mathrm{m}$. Using Rao and Bhupal's (1973) typology, they would be classified as astrosclereid or polyramous sclereids (Figure 1:30-31 and 39-42).

The sclereids found in my histological study of the $N$. odorata specimens were long and pin-shaped, rather than star shaped (Figure 6). These pin shaped sclereids are oriented parallel to the length of the peduncle and petiole, thus appear circular in cross-section (Figure 6A-D). Their length ranges from 1000-2000 $\mu \mathrm{m}$ and their width ranges from $10-60 \mu \mathrm{m}$. A distinguishing feature is a small protrusion at the mid-point of the sclereid (Figure 6E). Foliar sclereids differ from those in the petiole or peduncle and they are three times wider and branched (Figure 6F). Rao and Banerjee (1979) described N. odorata foliar sclereids from leaves as fusiform to polyramous. However, the morphology of sclereids from the peduncles (Figure 6C-E) and petioles (Figure 6A-B) I studied, more resemble polyramous (Figure 1: \#39-42) and librosclereids (Figure 1: \#34-36), than fusiform ones (Figure 2: \#18-21). The foliar sclereids in the specimens I examined (Figure 6F) resemble ramiform (Figure 1: \#24-29) or rhizosclereid (Figure 1: \#24-26) rather than fusiform types (Figure 2: \#24-26). Also, the sclereids from the 
petiole and peduncle resemble the same sclereids described by Gaudet (1960) in the same species (Figure 3).

The hot $\mathrm{KOH}$ treatment reduced the differences amongst sclereids. The sclereids from $N$. lutea peduncle are symmetrical star shaped astrosclereids (Figure 7A) and resemble the sclereids found during dissection (Figure 5A). After treatment, two types of sclereids were retrieved from the peduncle of $N$. odorata (Figure 7B). One resembles the librosclereids visible in live tissue (Figure 6A) and the other is an irregular star shaped sclereid, or polyramous sclereids, not observed in the live tissues. The sclereids from the petiole of both species are also different (Figure 7C-D). Again, N. lutea has symmetrical astrosclereids (Figure 7C) and N. odorata has long jagged librosclereids (Figure 7D). Foliar sclereids are also different between both species (Figure 7E-F). N. lutea has polyramous foliar sclereids (Figure 7E), but N. odorata has jagged and wide "T" shaped sclereids or rhizosclereid (Figure 7F). The sclereids found in the flower tissues are very similar, they both have sclereids ranging between astrosclereids to polyramous (Figure 7H-I). There is less variation of the shape of sclereids in $N$. lutea (astrosclereids and polyramous sclereid); on the other hand, $N$. odorata sclereids are variable within its tissue (librosclereids, polyramous, astrosclereid and rhizosclereids).

\section{Effect of conventional pollen processing on sclereids}

Sclereids of the two genera were conventionally processed with the combination of $\mathrm{KOH}$, acetolysis and HF and very different results were found (Figure 8).

Conventional pollen processing had little effect on $N$. lutea (Figure 8E-H), but dramatically altered $N$. odorata sclereids (Figure 8A-D). The straight librosclereids of $N$. odorata became undulated and almost unidentifiable. The polyramous sclereids found during the 
$\mathrm{KOH}$ processing (Figure 7B) were not found. The foliar sclereids found in histological examinations (Figure 6F) and after $\mathrm{KOH}$ (Figure 7F) were not visible after chemical processing. $N$. lutea sclereids found in all tissues, including the flower tissues were composed of the same astrosclereids or polyramous sclereids (Figure $8 \mathrm{E}-\mathrm{H}$ ). The sclereids found during the dissection (Figure 5) and the sclereids found after $\mathrm{KOH}$ processing (Figure 7A) are identical to these. The pollen from this species is also found after processing (Figure 8H). It would be safe to indicate that conventional pollen processing for pollen does not affect $N$. lutea sclereids.

Variation in duration of hot acetolysis treatment alone had distinctively different effects on $N$. lutea and $N$. odorata sclereids (Figure 9). Sclereids from $N$. odorata were severely affected by an acetolysis treatment after 3 and 5 min (Figure 9A-B). The shape of the pin shaped sclereids was no longer observed after 5 min of acetolysis (Figure 9A). After $10 \mathrm{~min}$, few sclereids were visible (Figure 9C). After 10 min acetolysis, $N$. lutea peduncular sclereids and pollen were still abundant and identifiable as the star shape was still visible, even though sclereids showed partial dissolution (Figure 9E-H).

Pollen and sclereids found in Shark River slough

The major pollen and sclereids counted in unsieved and sieved sediment samples are listed in Table 2 and the absolute count of all taxa can be found in appendix A. The major taxa found in order of abundance were: Chenopodiaceae/Amaranthaceae type (ChenoAm), Pinus, Nymphaea, Sagittaria and Morella. Abundance of other taxa was low, and only two Nuphar grains were found in all sediment samples (Appendix A).

The sclereids found had a variety of shapes and sizes (Figure 10 and 11) and fell into three morphological groups (Table 2). Type 1 sclereids were star shaped (Figure 10A-D), but it 
was impossible to classify them as polyramous or astrosclereids, since they are more altered then those found within fresh plant material. The Type 2 sclereids were "H" or "bone" shaped (Figure 10E-H). This sclereid type was difficult to classify, since the " $\mathrm{H}$ " shape resembles a trichosclereid in the typology (Figure 1: \#37-38), but the middle section of the Type 2 sclereids seem much longer compared to arms that extent outwards from the middle, however the middle section of the trichosclereids in Rao and Bhupal (1973) are much smaller compared to the arms (Figure 1:\#37-38). Also, these sclereids resemble somewhat the rhizosclereids depicted in the typology (Figure 1:\#24-26). Sclereids that did not appear to have any general shape were categorized as Type 3 (Figure 11), and because of their high abundance, only sclereids with a dimension $\geq 50 \mu \mathrm{m}$ were counted.

The effect of sieving on pollen and sclereid abundance

There is not much difference when sieved samples of major taxa (ChenoAm, Pinus and Nymphaea) are compared against unsieved samples on a 1:1 plot (Figure 12). The majority of the data points for ChenoAm are near the 1:1 line suggesting that this taxon isn't better represented in either sample. The majority of the data points for Pinus, Nymphaea, Morella and Sagittaria are below the 1:1 plot suggesting that these taxa are better represented in sieved samples. The change in percentages of Pinus, Nymphaea, Morella and Sagittaria is accompanied by the decreasing amount of other pollen category in sieved samples $(m=2.39)$. This means that sieving increases the percentages of major taxa while decreasing percentages of other taxa like Nuphar, Cephalanthus, Cyperaceae or Poaceae (Appendix 1). The size of ChenoAm grains ranges from 12-20 $\mu \mathrm{m}$, which is much smaller than the other taxa, which were: Pinus 35-50 $\mu \mathrm{m}$, Nymphaea 20-30 $\mu \mathrm{m}$, Morella 20-35 $\mu \mathrm{m}$, Sagittaria 20-30 $\mu \mathrm{m}$. This would mean that taxa with bigger 
pollen grain sizes are better represented in sieved samples and smaller taxa with high percentages like ChenoAm are unaffected by sieving.

A paired correlation test indicates that the percentages of most pollen taxa and sclereid types in sieved compared to unsieved samples were significantly correlated $(\mathrm{p}<0.05)$, with the exception of Sagittaria and Type 2 sclereids. Finally, a paired sample t-test confirms there is no difference in percentage of taxa or sclereid types in sieved vs. unsieved samples ( $p>0.05)$.

The variation of unsieved and sieved sclereid and pollen percentages through depth is illustrates in Figure 13. Type 1 sclereids are more abundant in the peat while the abundance of Type 2 in unsieved samples is greatest in the marl layer (Figure 13). Samples that weren't sieved had large sclereids ranging from 50-1000 $\mu \mathrm{m}$ (Figure 10A-B and Figure 11A-C) and samples that were sieved had sclereids that were less than $125 \mu \mathrm{m}$ (Figure 10C-D and Figure 11D). Type 2 sclereids were the same size for either method and ranged from 100-150 $\mu \mathrm{m}$ (Figure 10E-H).

Overall, the relative abundance of Nymphaea pollen, sclereids and markers abundance to total pollen does not seem to vary much when we compare samples that were sieved to those that were unsieved (Figure 13). Nymphaea pollen has its largest variation between $15-20 \mathrm{~cm}$ and at this point the variation is at its maximum of $13 \%$. After, sieved to unsieved variations stay below $5 \%$. The 3 sclereids types vary less than Nymphaea pollen (Figure 13).

In addition, all sclereid types have a mean absolute difference through depth below $\pm 3 \%$ and the Nymphaea pollen and Lycopodium markers are above 4\%. It seems that sieving has not affected the Type 1 sclereids percentages very much within the core. However, Type 2 sclereids were severely affected at $64 \mathrm{~cm}$, the absolute difference is about 15\% (Figure 13). This very large difference drives the absolute mean difference of this fossil, therefore making this last point 
an outlier. In brief, it seems that the exotic Lycopodium markers and most pollen from major taxa have much more variation in percentages through depth between sieving methods than the sclereid types.

\section{Sclereid interpretation}

There are no significant relationships between sclereids and Nymphaea pollen percentages (Pearson's correlation coefficients produced a $\mathrm{p}>0.5$ ). The Nymphaea pollen percentage is at a minimum at the lower level of the marl, suggesting that this species was less abundant or produced less pollen. Within the marl deposit, Nymphaea gradually increases in abundance until it reaches a plateau. If we compare sclereid types to Nymphaea pollen, Type 1 sclereids seem to follow the same pattern as Nymphaea pollen during the marl episode. Type 2 sclereid abundance shows a different pattern, peaking in the middle of the marl deposit (Figure 13). 


\section{Discussion}

\section{Sclereid morphology}

The limitation of the earlier classification of Rao and Banjerjee (1979) to foliar sclereids meant that the variability of sclereids in $N$. lutea and $N$. odorata was left unrecognized. My analysis reveals many other types of sclereids. In $N$. lutea, sclereid shape varies amongst the petiole, peduncle, and leaves and flowers. Peduncular and petiolar sclereids are symmetrical and are astrosclereids; sclereids from the leaves are less symmetrical and are polyramous sclereids. $N$. odorata sclereids not only vary between tissues, but in some tissues there is more than one type of sclereid.

My analyses indicate that the two most common water lily species: Nuphar lutea and Nymphaea odorata, as noted by Rao and Banerjee (1979), do not have trichosclereids. Neither histological examination, nor $\mathrm{KOH}$ treatment and nor conventional processing revealed trichosclereids retrieved from tissues of $N$. lutea or $N$. odorata. Yet, many paleoecological studies have referred to Nymphaeaceae sclereids as trichosclereids (Davidson et al., 2005, Kuhry, 1997, Miola et al., 2006, Pals et al., 1980, Pokorný et al., 2000, Ralska-Jasiewiczowa et al., 1992, Rikke et al., 2007, Shuman et al., 2009). I suspect that the use of the term "trichosclereid" probably originates with the reports by Pals et al. (1980) and who appropriately indicated that the "trichosclereids" were associated with the Nymphaeaceae, but misused the sclereid terminology. The more appropriate terms would have been polyramous or astrosclereid for $N$. lutea and librosclereid, ramiform, rhizosclereids or polyramous for $N$. odorata. More importantly, some studies have associated "trichosclereids" with Nymphaea (Shuman et al., 2009), yet sclereids of the most common Nymphaea species, $N$. odorata are unlikely to be visible 
after the acetolysis treatments used by most palynologists. This opens the possibilities for misinterpretation of a species' presence.

\section{Effect of pollen processing on sclereids}

Sclereids of $N$. odorata were difficult to identify after conventional pollen processing because their shape was lost (Figure 8A-C). The pollen processing step that caused this was acetolysis, verified by the acetolysis experiment (Figure 9A-C). On the other hand, N. lutea sclereids resist conventional pollen processing and are easily identified after extended acetolysis treatments (Figure 8 and 9). The differential survival of the sclereids of these species is probably due to their shapes. The star shaped $N$. lutea sclereids have less surface area for their volume than "pin" shaped or librosclereids. Because N. lutea can survive long acetolysis treatments, this species is most likely the source of the star-shaped sclereids observed by earlier researchers (Arsenault et al., 2007, Davidson et al., 2005, Eide et al., 2006, Kuhry, 1997, Miola et al., 2006, Pals et al., 1980, Pokorný et al., 2000, Ralska-Jasiewiczowa et al., 1992, Rikke et al., 2007, Shuman et al., 2009, Warner, 1984). After conventional processing it is impossible to differentiate between astrosclereids and polyramous sclereids, but the star shape can be recognized.

The ability to detect resistant sclereids seems unaffected by sieving as a paired t-test showed no significant difference between sclereids percentages in sieved and unsieved sediments from the Everglades Slough sediments $(\mathrm{p}>0.05)$. Sieving may increase visibility within pollen slides and this would make small sclereids easier to see. On the other hand, if samples are not sieved, visibility is decreased and only large sclereid $>125 \mu \mathrm{m}$ are counted. If a researcher 
prefers not to sieve, the same amount of sclereids will be counted, however their size will be larger.

Sclereid interpretation

There was no correlation between sclereid types and Nymphaea pollen (Pearson correlation coefficient $p>0.05$ ). Type 2 sclereids are abundant in the marl layer (Figure 13), but their source is unknown; it is quite possible that they originated from Nymphaea leaves (Figure 7F) or from an entirely different species. They are abundant in the middle of the marl layer and this is possibly caused by the response of this species of origin to drier condition. Nymphaeaceae species respond to decreased water levels by growing aerial leafs rather than "lily pads" (Titus and Sullivan, 2001). This means that during drier conditions there are more aerial leaves and less aquatic leaves (lily pads). An increase in aerial leaves would also increase the abundance of sclereids, since aerial leaf have been shown to have a higher density of sclereids (Etnier and Villani, 2007). 


\section{Conclusions}

In paleocological literature, the taxonomic affinity of Nymphaeaceae sclereids has been confused. They have been referred to as sclereid, astrosclereid, trichosclereid without verifying if the term fits the correct classification from Rao and Bhupal (1973). Some paleoecological studies have referred to Nymphaeaceae sclereids as trichosclereids, however the sclereids found within common species of this family ( $N$. lutea and $N$. odorata) are not trichosclereids. Furthermore, the sclereids from these species can be differentiated before conventional pollen processing, but only the sclereids from $N$. lutea can survive pollen processing in a detectable form. As a result, sclereids from $N$. lutea can be a useful indicator of its presence in sediment, but the major limitation to using sclereids as a proxy is that they originate from plant tissues; if they aren't released from this matrix they stay hidden inside the tissue. Acetolysis treatments digest organic matter and sclereid retrieval is dependent on this treatment to release sclereids from peat. The chance of observing sclereids from $N$. odorata in pollen preparation is very low, thus have low utility as a paleoecological indicator. Additional analyses are required to determine if empirical relationships exist amongst plant populations, pollen, sclereids and environmental conditions. A clear report of chemical treatments used and processing times are critical to verify results of studies utilizing sclereids.

Maximizing retrieval of Nuphar sclereids can be obtained by prolonged acetolysis treatment, however, long acetolysis treatments can also degrades pollen (Moore et al., 1991).

The interpretation of these sclereids is also problematic, star shaped sclereids are easily counted on pollen slides, but their size is variable and one can encounter excessive amounts of sclereid fragments during counting. 
Sclereids are not only found in peat layer, in the current study sclereids were retrieved from a marl layer and it was found that Type 2 sclereid percentage peaked in this deposit. Because the origin of Type 2 sclereids is unknown, the peak in the marl layer cannot be interpreted. Nevertheless, I suggest two explanations: 1) The increase in abundance of this type of sclereids is probably due to the biological adaptation of the plant species the sclereid originates from, 2) during the marl period there were increased decompositions rates, which decomposed the tissue matrix the sclereids were trapped in, consequently more sclereids were released from the organic matter during pollen processing. 
Table 1. Comparative paleoecological concentration methods based on studies which have found sclereids in their microfossils and macrofossils samples

\begin{tabular}{|c|c|c|c|c|}
\hline \multirow{2}{*}{ Study } & \multicolumn{2}{|l|}{ Microfossils } & \multicolumn{2}{|l|}{ Macrofossils } \\
\hline & Chemicals & Sieving & Chemicals & Sieving \\
\hline Kuhry, 1997 & $\begin{array}{l}\mathrm{HCl}, 10 \% \mathrm{KOH} \text {, Acetolys is, } 10 \% \mathrm{Na}- \\
\text { pyrophosphate, and Bromoform-alcohol }\end{array}$ & None reported & Hot $5 \% \mathrm{KOH}$ & $>150 \mu \mathrm{m}$ \\
\hline Pokorný et al., 2000 & Acetolys is and cold $35 \% \mathrm{HF} 24 \mathrm{hrs}$ & None reported & $5 \% \mathrm{KOH} 5 \mathrm{~min}$ & {$[200-700] \mu \mathrm{m}$} \\
\hline Warner, 1984 & $\begin{array}{l}10 \% \mathrm{HCl}, \mathrm{HF} \text { overnight, Hot } 6 \% \mathrm{KOH} 10 \\
\text { min, Acetolys is } 1 \mathrm{~min} \text { and Sodium } \\
\text { Hexametaphosphate }\end{array}$ & {$[7-250] \mu \mathrm{m}$} & Cold $6 \% \mathrm{KOH}$ overnight & $>250 \mu \mathrm{m}$ \\
\hline Arsenault, 2004 & $\begin{array}{l}10 \% \mathrm{HCl} \text {, Hot } 10 \% \mathrm{KOH} 10 \mathrm{~min} \text {, Hot HF } 12 \\
\text { min, acetolys is }\end{array}$ & {$[7-500] \mu \mathrm{m}$} & None reported & None reported \\
\hline Shuman et al., 2009 & Faegri and Ivers en (1989) & None reported & None reported & $>125 \mu \mathrm{m}$ \\
\hline Pals et al., 1980 & $\begin{array}{l}\mathrm{KOH}, \text { Acetolys is, } \mathrm{HF} \text {, Hot 5\% KOH 5-10 } \\
\min \end{array}$ & None reported & Hot $5 \% \mathrm{KOH} 5-10 \mathrm{~min}$ & $>160 \mu \mathrm{m}$ \\
\hline Ralska-Jas iewiczowa et al., 1992 & $\begin{array}{l}\mathrm{Na}_{4} \mathrm{P}_{2} \mathrm{O}_{7} \text {, Acetolysis and Bromoform- } \\
\text { alcohol }\end{array}$ & None reported & None reported & None reported \\
\hline Rikke B., 2007 & $\begin{array}{l}\text { Standard procedures (Fægri, 1989) } \\
\text { including HF to dissolve small inorganic } \\
\text { particles }\end{array}$ & None reported & None reported & $>140 \mu \mathrm{m}$ \\
\hline Davidson et al., 2005 & None reported & None reported & None reported & {$[350-150] \mu \mathrm{m}$} \\
\hline Eide et al., 2006 & $\begin{array}{l}\text { Method B of Berglund and Ralska- } \\
\text { Jasiewizowa (1986) }\end{array}$ & None reported & $\mathrm{Na} 4 \mathrm{P} 2 \mathrm{O} 7 \mathrm{H} 2 \mathrm{O} 1$ hour or $10 \% \mathrm{KOH}$ & $>125 \mu \mathrm{m}$ \\
\hline Miola et al., 2006 & $\begin{array}{l}10 \% \mathrm{HCl} \text {, hot } 10 \% \mathrm{NaOH} \text {, cold } 50 \% \mathrm{HF} \text {, } \\
\text { acetolys is }\end{array}$ & $<200 \mu \mathrm{m}$ & Hot $10 \% \mathrm{NaOH}$ few min & $>200 \mu \mathrm{m}$ \\
\hline
\end{tabular}

* Shaded boxes are where sclereids were found 
Table 2. Palynomorph counts from Everglades Slough sediments

\begin{tabular}{|c|c|c|c|c|c|c|c|c|c|c|c|c|c|c|c|c|c|c|c|c|c|c|c|c|c|}
\hline \multirow[t]{2}{*}{ Lithology } & \multirow[t]{2}{*}{ Depth (cm) } & \multicolumn{2}{|c|}{ ChenoAm } & \multicolumn{2}{|c|}{ Pinus } & \multicolumn{2}{|c|}{ Nymphaea } & \multicolumn{2}{|c|}{ Sagittaria } & \multicolumn{2}{|c|}{ Morella } & \multicolumn{2}{|c|}{$\begin{array}{l}\text { Other } \\
\text { Grains }\end{array}$} & \multicolumn{2}{|c|}{ Total Grains } & \multicolumn{2}{|c|}{ Lycopodium } & \multicolumn{2}{|c|}{$\begin{array}{c}\text { Type } 1 \\
\text { sclereids }\end{array}$} & \multicolumn{2}{|c|}{$\begin{array}{c}\text { Type } 2 \\
\text { sclereids }\end{array}$} & \multicolumn{2}{|c|}{$\begin{array}{c}\text { Type } 3 \\
\text { sclereids }\end{array}$} & \multicolumn{2}{|c|}{$\begin{array}{c}\text { Total } \\
\text { sclereids }\end{array}$} \\
\hline & & U-s* & $s$ & U-S & $\mathrm{s}$ & U-S & $\mathrm{s}$ & U-S & $s$ & U-S & $\mathrm{s}$ & U-S & $\mathrm{s}$ & U-S & $\mathrm{s}$ & U-S & $\mathrm{s}$ & U-S & $\mathrm{s}$ & U-S & $\mathrm{s}$ & U-S & $\mathrm{s}$ & U-S & $s$ \\
\hline Peat & $\begin{array}{l}15-18 \\
\end{array}$ & 66 & 35 & 61 & 61 & 63 & 102 & 9 & 16 & 30 & 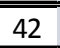 & 92 & 57 & 321 & 313 & 137 & 139 & 18 & 10 & ב5 & 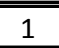 & 12 & 6 & 35 & 17 \\
\hline Peat & $24-26$ & 120 & 104 & 89 & 146 & 32 & 56 & 20 & 4 & 6 & 11 & 39 & 19 & 306 & 340 & 42 & 67 & 9 & 17 & 8 & 13 & 18 & 37 & 35 & 67 \\
\hline Marl & $32-33$ & 121 & 170 & 62 & 79 & 32 & 23 & 7 & 20 & 15 & 26 & 68 & 22 & 305 & 340 & 55 & 90 & 7 & 19 & 6 & 9 & 8 & 13 & 21 & 41 \\
\hline Marl & $36-40$ & 172 & 121 & 83 & 125 & 32 & 25 & 4 & 11 & 5 & 2 & 34 & 29 & 330 & 313 & 100 & 134 & 14 & 7 & 53 & 46 & 3 & 4 & 70 & 57 \\
\hline Marl & 44-47 & 192 & 198 & 71 & 87 & 6 & 11 & 21 & 14 & 6 & 2 & 26 & 17 & 322 & 329 & 141 & 166 & 2 & 5 & 0 & 2 & 1 & 9 & 3 & 16 \\
\hline Peat & $47-49$ & 300 & 283 & 24 & 21 & 13 & 28 & 2 & 6 & 0 & 0 & 4 & 17 & 343 & 355 & 27 & 16 & 6 & 2 & 4 & 0 & 6 & 6 & 16 & 8 \\
\hline Peat & 53-55 & 233 & 223 & 46 & 50 & 41 & 29 & 6 & 8 & 1 & 0 & 10 & 10 & 337 & 320 & 22 & 30 & 9 & 6 & 7 & 1 & 22 & 4 & 38 & 11 \\
\hline Peat & 63-65 & 235 & 235 & 40 & 47 & 20 & 29 & 6 & 6 & 0 & 0 & 13 & 9 & 314 & 326 & 18 & 25 & 50 & 28 & 52 & 5 & 63 & 66 & 165 & 99 \\
\hline \multicolumn{2}{|c|}{ Total } & 1439 & 1369 & 476 & 616 & 239 & 303 & 75 & 85 & 63 & 83 & 286 & 180 & 2578 & 2636 & 542 & 667 & 115 & 94 & 135 & 77 & 133 & 145 & 383 & 316 \\
\hline \multicolumn{2}{|c|}{ Mean } & 180 & 171 & 60 & 77 & 30 & 38 & 9 & 11 & 8 & 10 & 36 & 23 & 322 & 330 & 68 & 83 & 14 & 12 & 17 & 10 & 17 & 18 & 48 & 40 \\
\hline
\end{tabular}




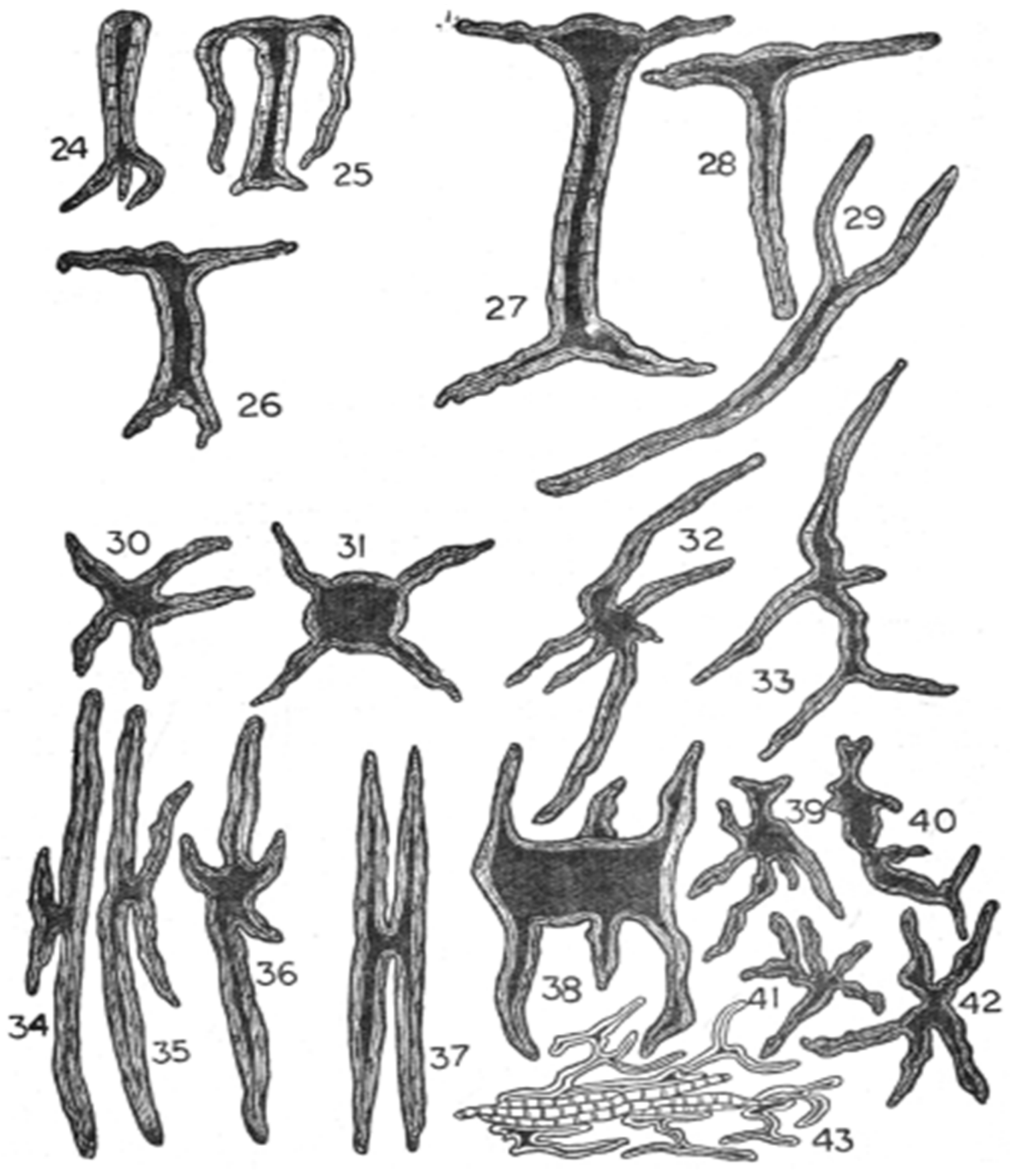

Figure 1. Polymorphic or branched sclereid topology from Rao and Bhupal (1973). Ramiform sclereids (\#24-29): Rhizosclereid (\#24-26 and I-shaped sclereid (\#27-29); Astrosclereids (\#3031): Astrosclereids (\#30-31), Ophiurosclereid (\#32-33), Librosclereid (\#34-36) and Trichosclereid (\#37-38); Polyramous sclereids (\#39-42); Idiofibrosclereid (\#43). Figure adapted from Rao and Bhupal (1973). 

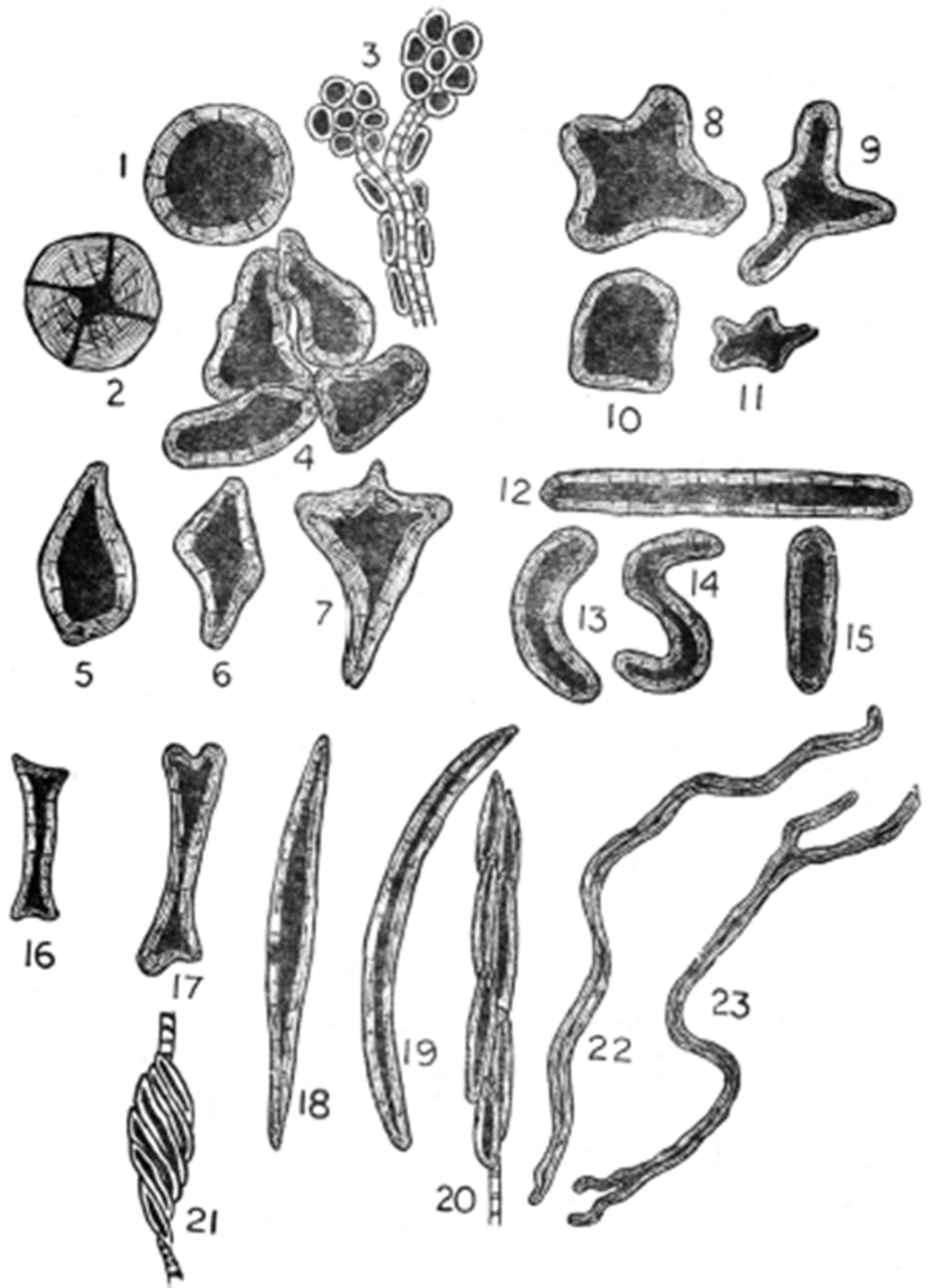

Figure 2. Other sclereid typess from Rao and Bhupal (1973). Spheroidal (\#1-7). Vesiculose Sclereid (\#8-11), Vermiform Sclereid (\#12-15), Palosclereids (\#16), Osteosclereids (\#17), Fusiform Sclereid (\#18-21), Filiform Sclereid (\#22-23). Figure adapted from Rao and Bhupal (1973). 


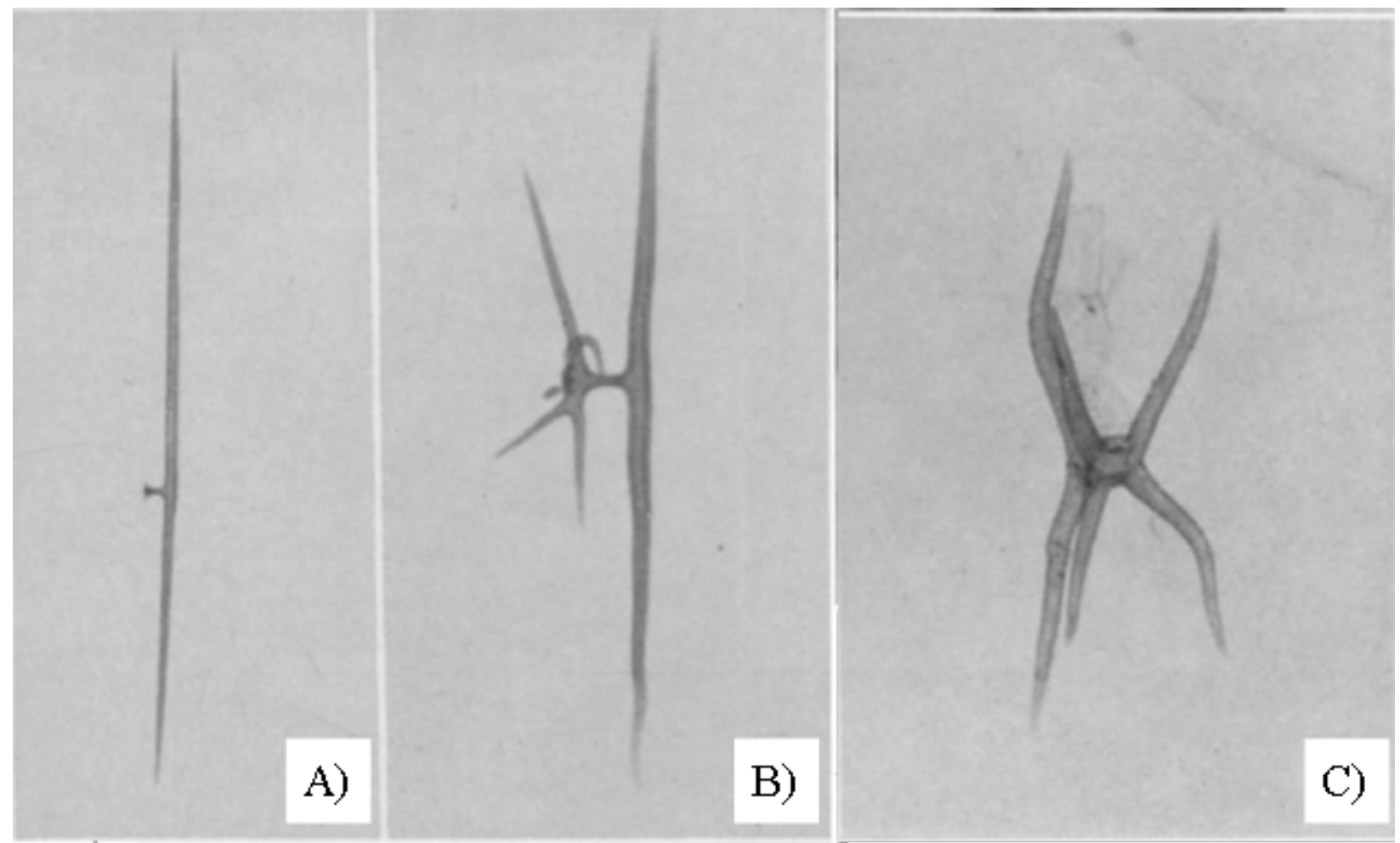

Figure 3. Petiolar sclereids from Nymphaea odorata from a study by Gaudet (1960). A) Described as an "I" shaped sclereids. B) Described as an "I" to "H" shaped sclereid. C) Described as an "H" shaped sclereid. Figures adapted from Gaudet (1960). 


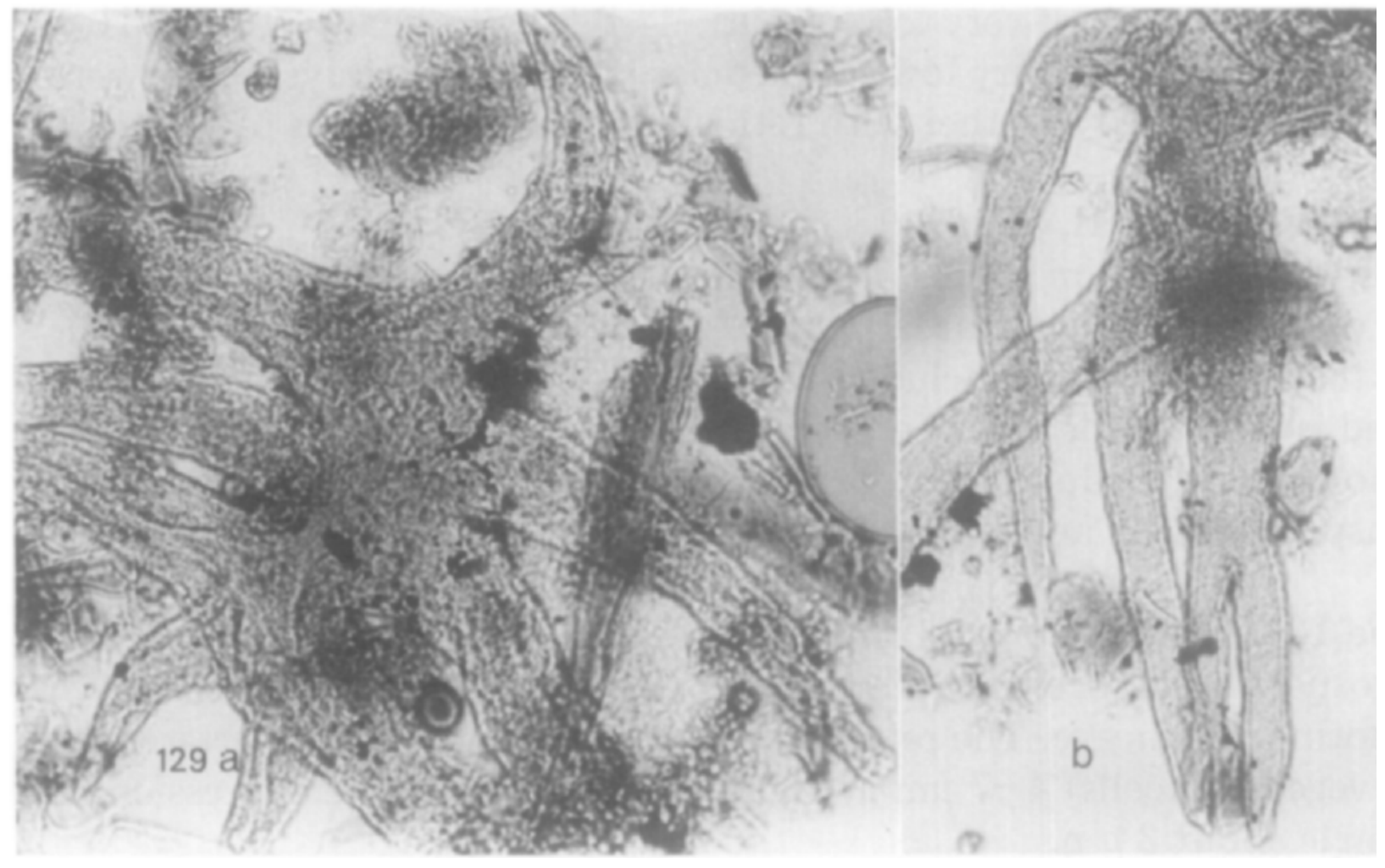

Figure 4. Type 129 Trichosclereids from Nymphaeaceae from a study by Pals et al. (1980). The same author mentions that the total diameter is $0.2-0.3 \mathrm{~mm}$. Figures adapted from Pals et al. (1980). 


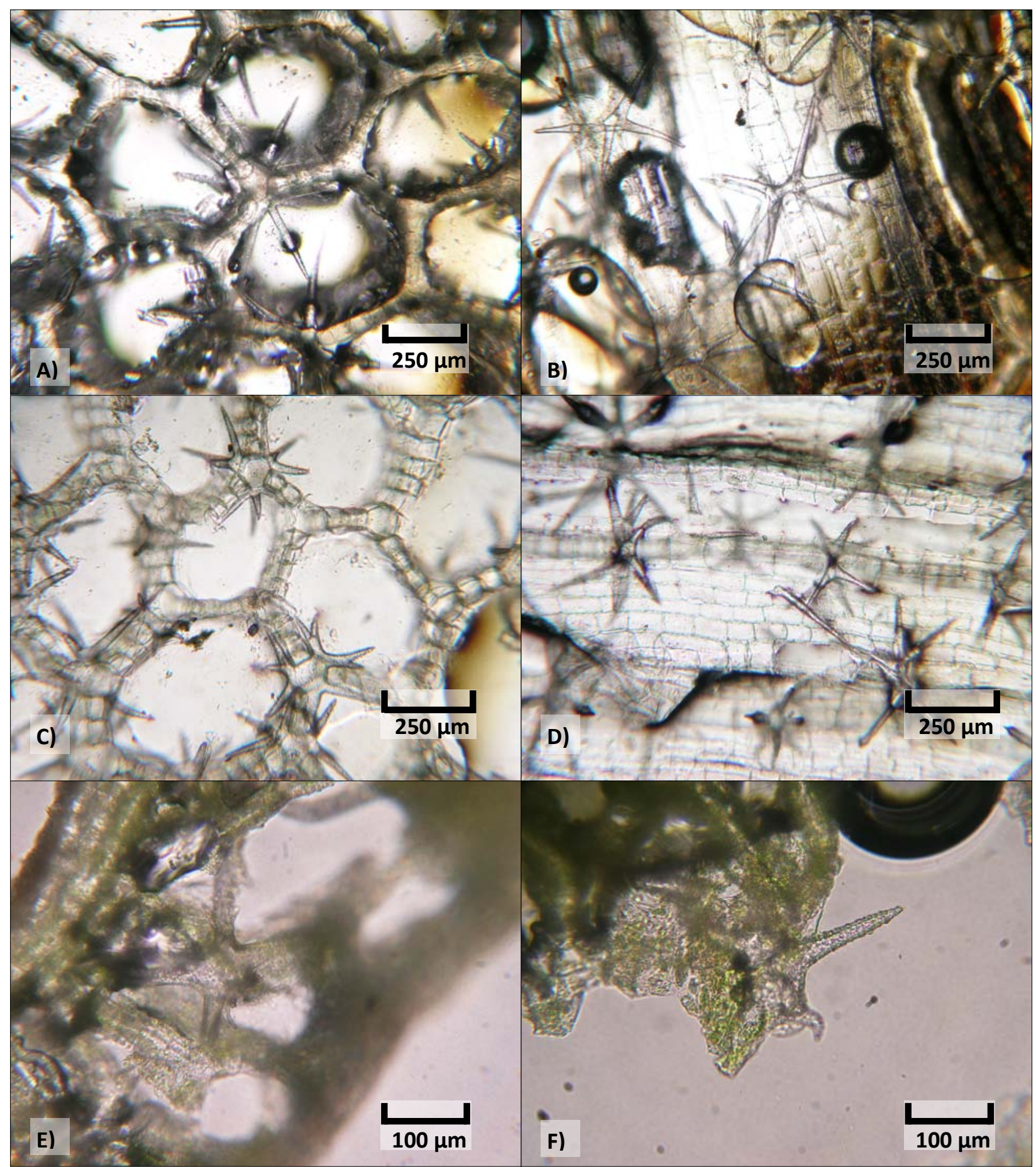

Figure 5. Shape and size of sclereids found within plant tissues of $N$. lutea. A) Cross-section of the peduncle showing star-shaped sclereids. B) Transverse-section also showing star-shaped sclereids. C) Cross-section of the petiole showing star-shaped sclereids. D) Transverse-section of the petiole also showing star-shaped sclereids. E) Cross-section of the leaf or lily-pad showing star-shaped sclereids. F) Star-shaped sclereid found within the leaf tissue. 


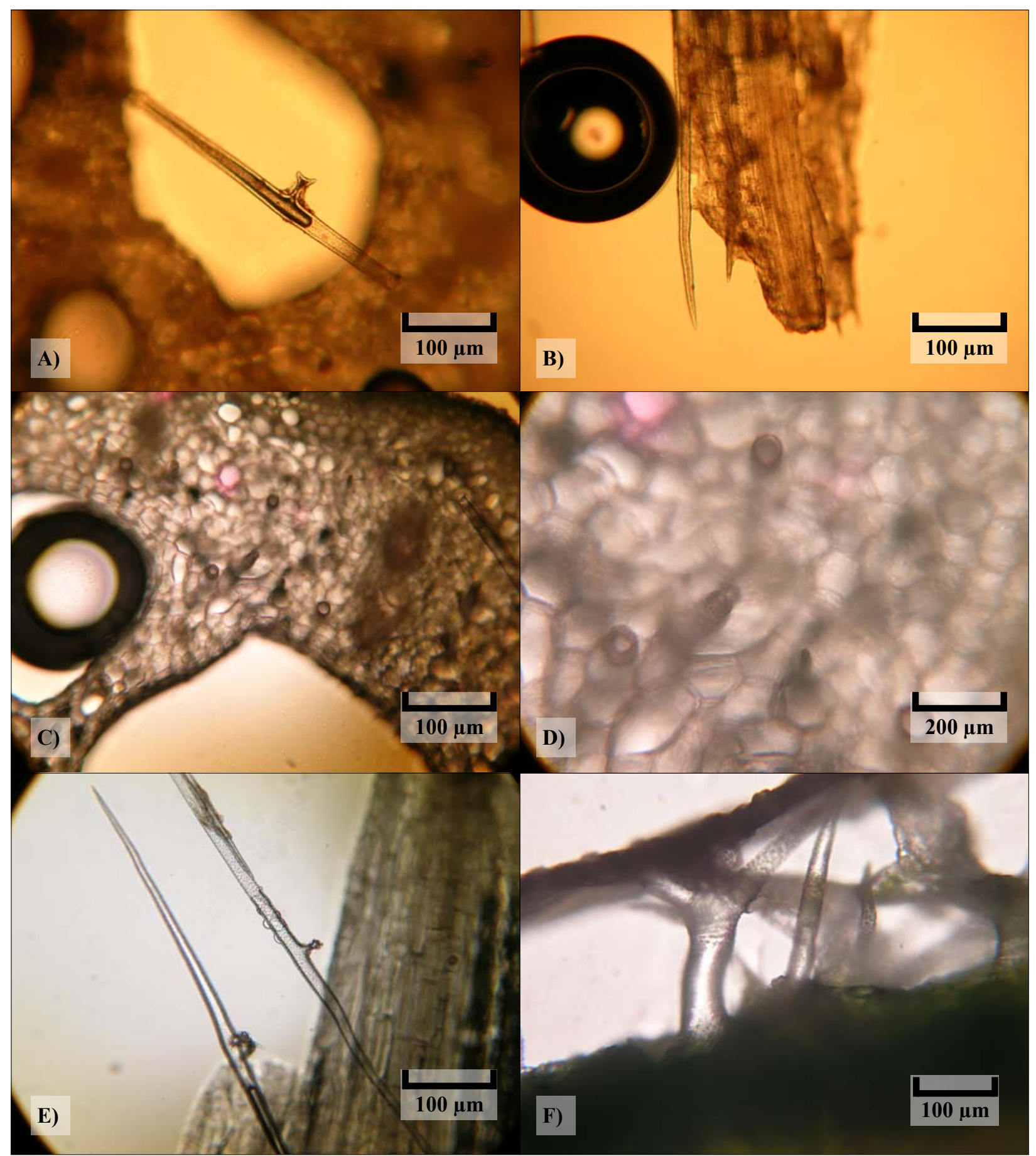

Figure 6. Shape and size of sclereids found within plant tissues of $N$. odorata. A) Cross-section of the petiole with a long Pin shaped sclereid. B) Transverse-section of the petiole with long sclereids forming the structure of the tissue. C) Cross-section of the peduncle with no noticeable sclereids. D) Same as C) but a closer look at the round cross-sections of sclereids indicating that within Nymphaea odorata long sclereids run parallel to the stem. E) Transverse-section of the peduncle showing long sclereids. F) Cross-section of the leaf or lily-pad, showing a large cluster of sclereids with different shapes than the petiole and peduncle. 


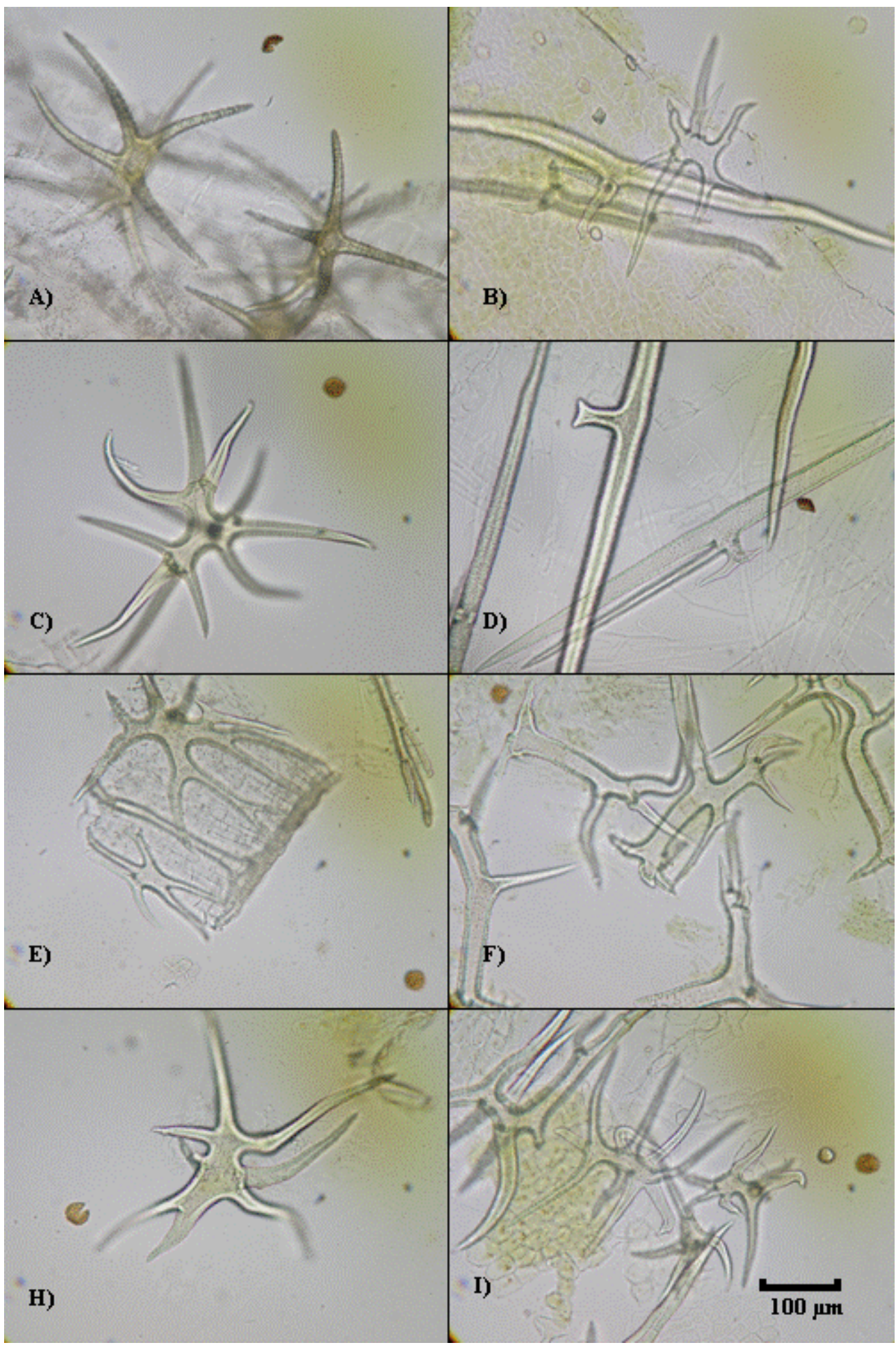

Figure 7. Sclereids from $N$. lutea tissues on the left and $N$. odorata tissues on the right after a $10 \mathrm{~min} \mathrm{KOH}$ treatment. A-B) Peduncular sclereids. C-D) Petiolar sclereids. E-F) Leaf sclereids. H-I) flower sclereids 


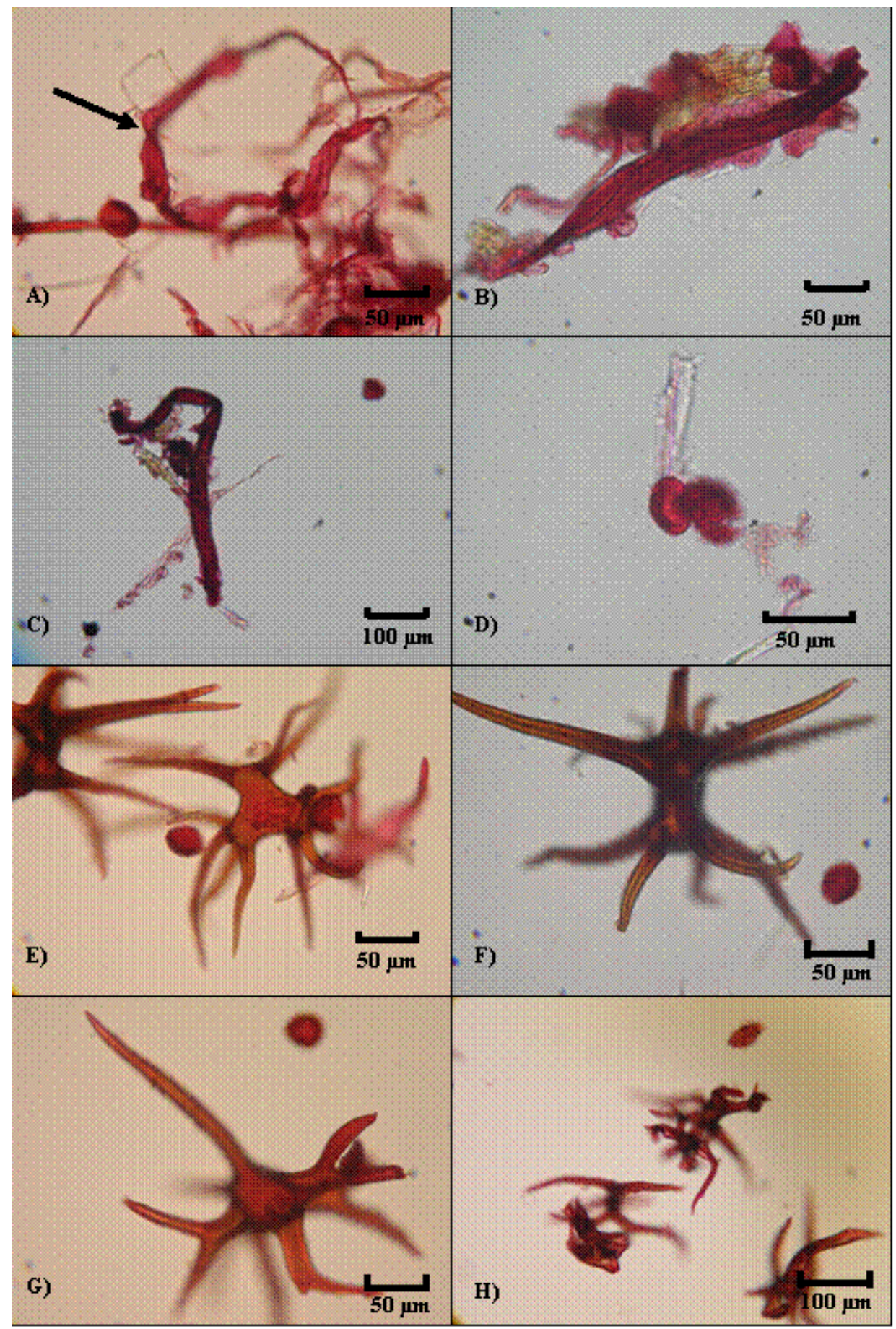

Figure 8. $N$. odorata and $N$. lutea sclereids and Lycopodium after conventional pollen processing. A-D) $N$. odorata sclereids: A) Peduncular sclereids, B-C) petiolar sclereids and D) $N$. odorata pollen with a Lycopodium maker. E-H) $N$. lutea sclereids: E) Peduncular sclereids, F) petiolar sclereids, G) foliar sclereids and H) flower sclereids. 


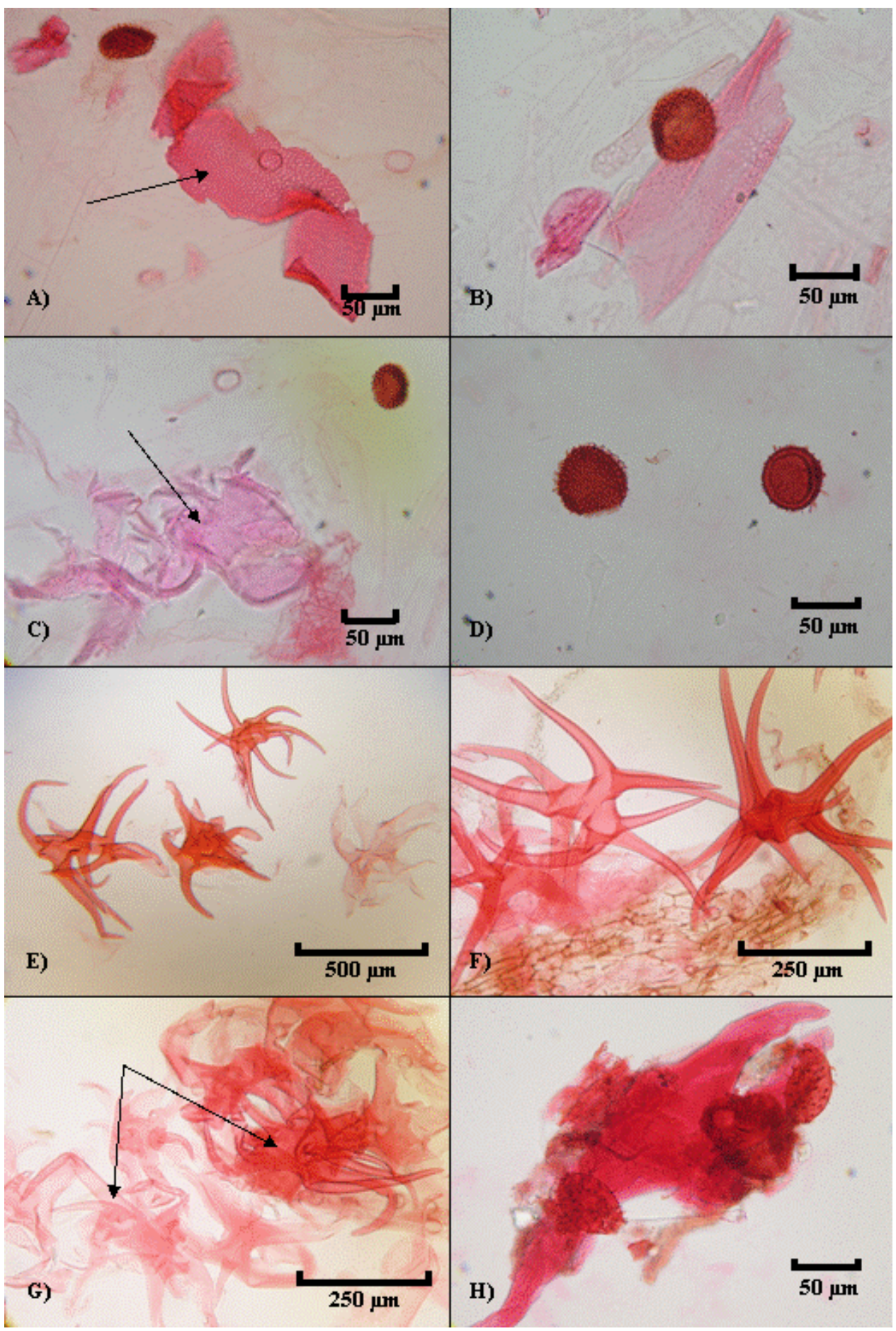

Figure 9. $N$. odorata and $N$. lutea sclereids after $5 \mathrm{~min}$ and $10 \mathrm{~min}$ acetolysis treatment. A- B) $N$. odorata peduncular sclereids after 5 min of acetolysis, the oxalate crystals are still visible. C) $N$. odorata peduncular sclereids after 10 min of acetolysis. D) $N$. odorata pollen after $10 \mathrm{~min}$ of acetolysis. E-G) Peduncular sclereids of $N$. lutea after 10 min of acetolysis: $G$ ) The star shape is still noticeable even in heavily affected sclereids. H) Pollen of $N$. lutea after 10 min of acetolysis. 


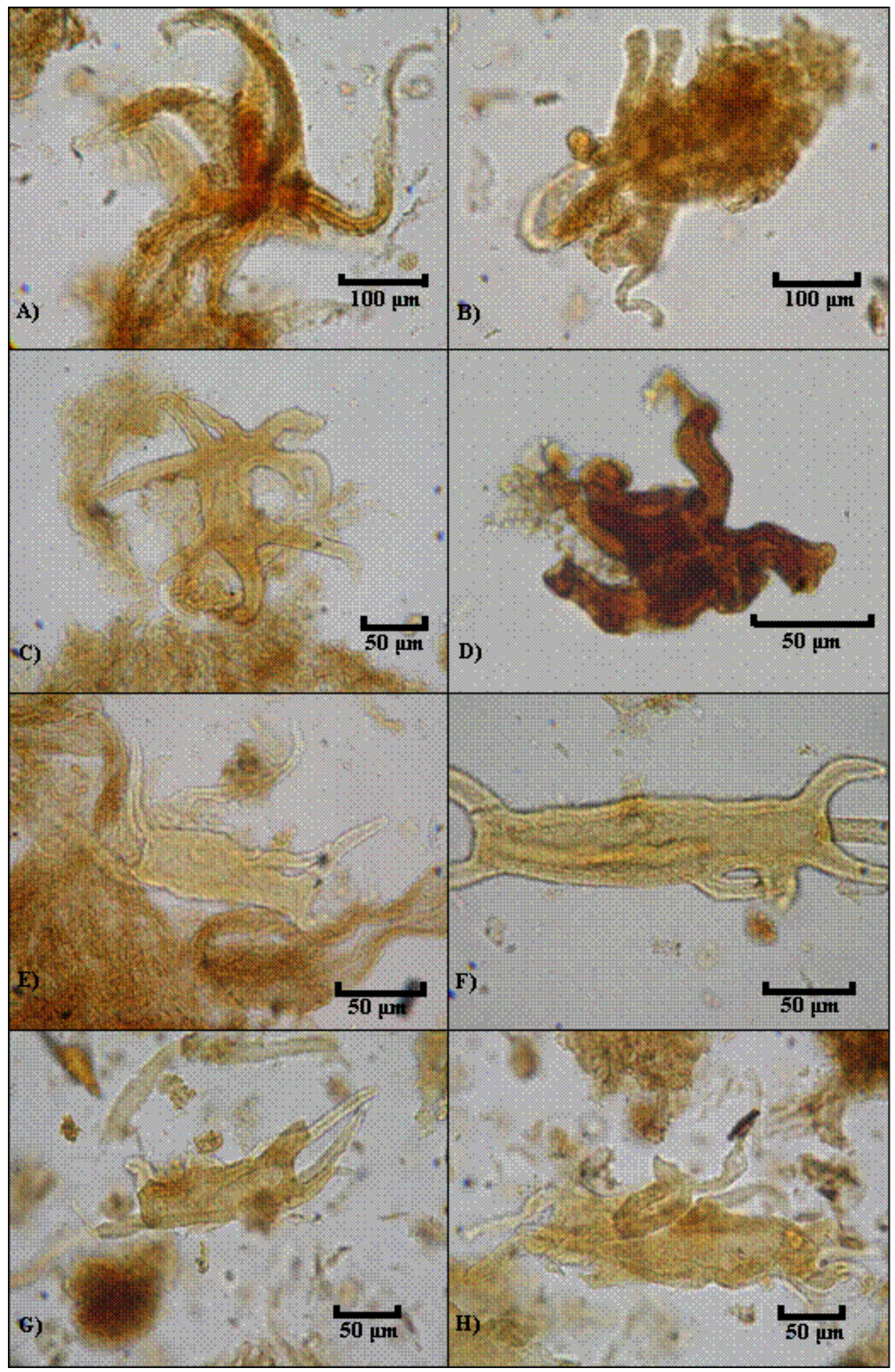

Figure 10. Sclereids from Everglades Slough sediments. A-D) Type 1 sclereids or Star shaped sclereids: A-B) are from unsieved samples and C-D) are from sieved samples (125 $\mu \mathrm{m}$ mesh). E-H Type 2 sclereids or Bone shaped: E-F) are from unsieved samples and G-H) are from sieved samples (125 $\mu \mathrm{m}$ mesh). 


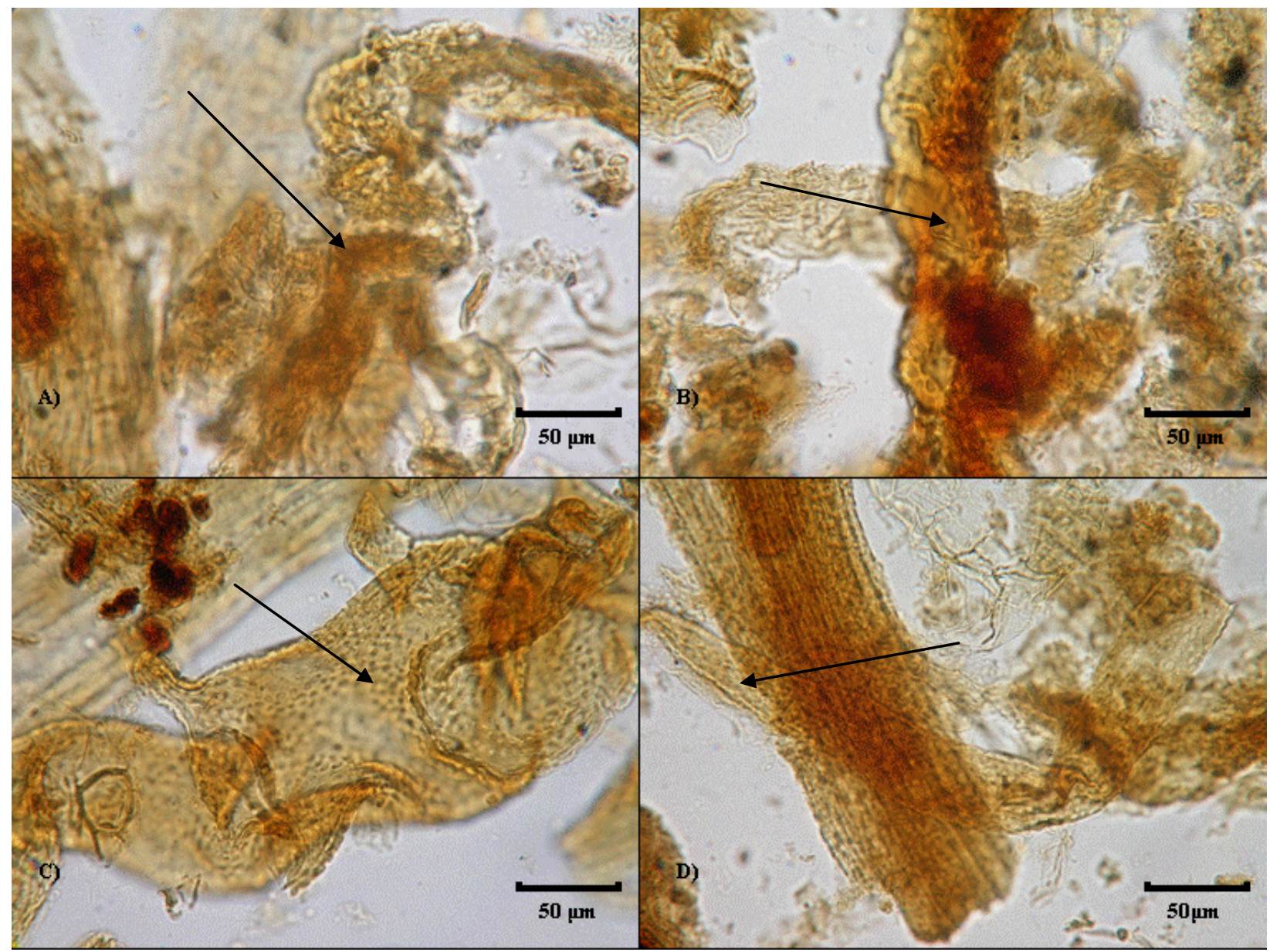

Figure 11. Sclereids from Everglades slough sediments, all of these sclereids were classified as Type 3 sclereids, since their form is severely altered and they do not seem to have a defined star or "H" shape, they are however long. A-B) Possible libroseclereids from Nymphaea. C) Very altered sclereid, the oxylate crystals are still visible. D) Possible fragment from a star shaped sclereid or a librosclereid. 


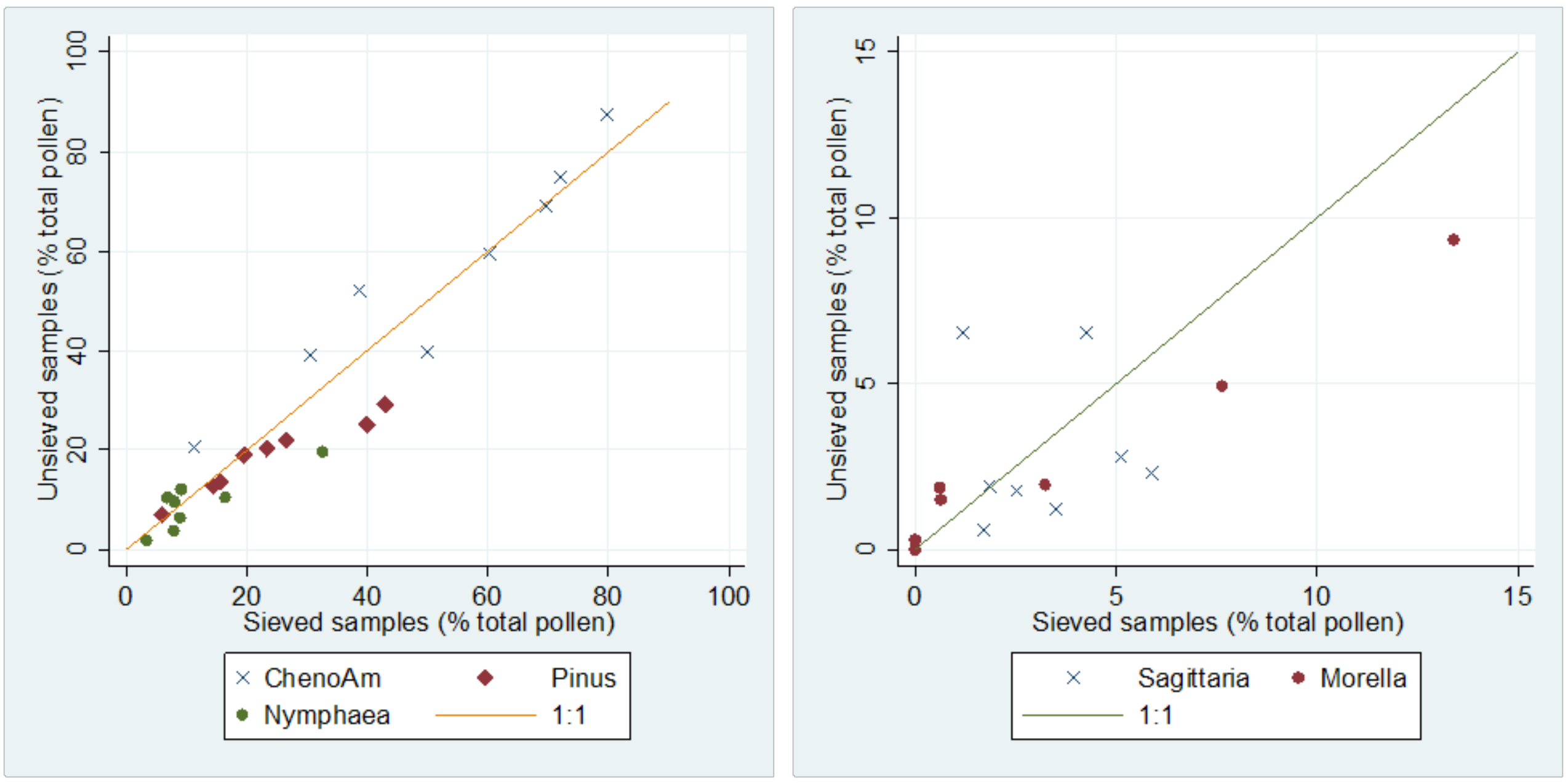

Figure 12. Scatter plots which show relationship between unseived and sieved samples for pollen from Everglades Slough sediments. 


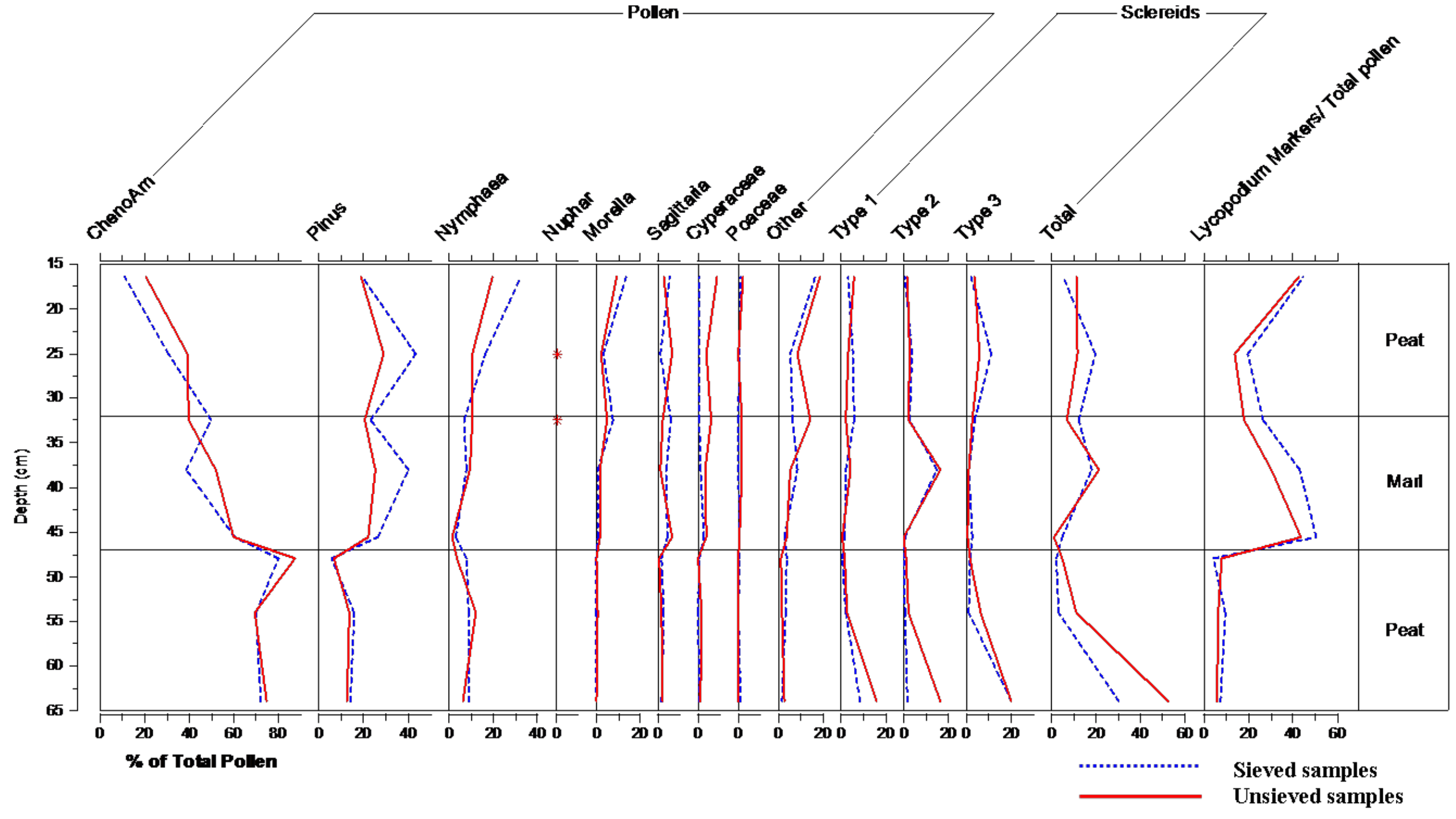

Figure 13. Pollen plot through depth comparing pollen, sclereid types and Lycopodium markers for unsieved and sieved samples from Everglades Slough sediments. Lycopodium markers are not included in the total pollen count. 


\section{References}

ARSENAULT, T. A., CLAGUE, J. J. \& MATHEWES, R. W. 2007. Late Holocene vegetation and climate change at Moraine Bog, Tiedemann Glacier, southern Coast Mountains, British Columbia. Canadian Journal of Earth Sciences, 44, 707-719.

BERCU, R. 2003. Some histological and cytological features of four hydrophytes occurring in the Danube Delta (Romania). Contr. Bot. Univ. "Babes-Bolyai" Cluj-Napoca, 38, 127134.

BRODRIBB, T. J., FEILD, T. S. \& SACK, L. 2010. Viewing leaf structure and evolution from a hydraulic perspective. Functional Plant Biology, 37, 488-498.

CONARD, H. S. 1905. A Monograph of the Genus Nymphæa. The Waterliles. Carnegic Institution of Washington.

DAVIDSON, T. A., SAYER, C. D., BENNION, H., DAVID, C., ROSE, N. \& WADE, M. P. 2005. A 250 year comparison of historical, macrofossil and pollen records of aquatic plants in a shallow lake. Freshwater Biology, 50, 1671-1686.

EIDE, W., BIRKS, H. H., BIGELOW, N. H., PEGLAR, S. M. \& BIRKS, H. J. B. B. 2006. Holocene forest development along the Setesdal valley, southern Norway, reconstructed from macrofossil and pollen evidence. Vegetation History and Archaeobotany, 15, 65-85.

ETNIER, S. A. \& VILLANI, P. J. 2007. Differences in mechanical and structural properties of surface and aerial petioles of the aquatic plant Nymphaea odorata subsp Tuberosa (Nymphaeaceae). American Journal of Botany, 94, 1067-1072. 
FAEGRI, K. \& IVERSEN, J. 1975. Textbook of pollen analysis, New York, Hafner Press.

FAEGRI, K. \& IVERSEN, J. 1989. Textbook of pollen analysis, Chichester [England] ; New York, Wiley.

FAHN, A. 1974. Plant anatomy, Oxford ; New York, Pergamon Press.

GAUDET, J. 1960. Ontogeny of the foliar sclereids in Nymphaea odorata. American Journal of Botany, 47, 525-532.

HESSE, M. \& WAHA, M. 1989. A New Look at the Acetolysis Method. Plant Systematics and Evolution, 163, 147-152.

KAPP, R. O., DAVIS, O. K. \& KING, J. E. 2000. Ronald O. Kapp's pollen and spores, College Station, TX, American Association of Stratigraphic Palynologists Foundation.

KUHRY, P. 1997. The palaeoecology of a treed bog in western boreal Canada: A study based on microfossils, macrofossils and physico-chemical properties. Review of Palaeobotany and Palynology, 96, 183-224.

LOVELESS, C. M. 1959. A Study of the Vegetation in the Florida Everglades. Ecology, 40, 2-9.

MAUSETH, J. D. 1988. Plant anatomy, Menlo Park, Calif., Benjamin/Cummings Pub. Co.

MCANDREWS, J. H., BERTI, A. A. \& NORRIS, G. 1973. Key to the Quaternary pollen and spores of the Great Lakes region, [Ottawa], Royal Ontario Museum.

MIOLA, A., BONDESAN, A., CORAIN, L., FAVARETTO, S., MOZZI, P., PIOVAN, S. \& SOSTIZZO, I. 2006. Wetlands in the Venetian Po Plain (northeastern Italy) during the 
Last Glacial Maximum: Interplay between vegetation, hydrology and sedimentary environment. Review of Palaeobotany and Palynology, 141, 53-81.

MOORE, P. D., WEBB, J. A. \& COLLINSON, M. E. 1991. Pollen analysis, Oxford ; Malden, MA, Blackwell Science.

OGDEN, E. C. 1974. Anatomical Patterns of Some Aquatic Vascular Plants of New York. Bulletin No 424.

PADGETT, D. J. 2007. A monograph of Nuphar (Nymphaeaceae). Rhodora, 109, 1-95.

PALS, J. P., VAN GEEL, B. \& DELFOS, A. 1980. Paleoecological studies in the Klokkeweel bog near hoogkarspel (prov. of Noord-Holland). Review of Palaeobotany and Palynology, 30, 371-418.

POKORNÝ, P., KLIMEŠOVÁ, J. \& KLIMEŠ, L. 2000. Late holocene history and vegetation dynamics of a floodplain alder carr: A case study from eastern Bohemia, Czech Republic. Folia Geobotanica, 35, 43-58.

RALSKA-JASIEWICZOWA, M., GEEL, B. V., GOSLAR, T. \& KUC, T. 1992. The record of the Late Glacial/Holocene transition in the varved sediments of lake Goscias, central Poland, Uppsala, SUEDE, Sveriges geologiska unders\&\#246;kning.

RAO, T. A. \& BANERJEE, B. C. 1979. On foliar sclereids in the Nymphaeaceae sensu lato and their use in familial classification. Proceedings of the Indian Academy of Sciences-Plant Sciences, 88, 413-\&. 
RAO, T. A. \& BHUPAL, O. P. 1973. Typology of Sclereids. Proceedings of the Indian Academy of Sciences Section B, 77, 41-55.

RIKKE, B., SIMONSEN, C. E. A., ODGAARD, B. V., BUCHARDT, B., MCGOWAN, S., LEAVITT, P. \& JEPPESEN, E. 2007. Climate-driven regime shift related to changes in water level: a decadal scale multiproxy study of the 8.2 kyr. cooling event in Lake Sarup (Denmark). Department of Freshwater Ecology. Denmark: Department of Biological Sciences, University of Aarhus.

SHUMAN, B., HENDERSON, A. K., PLANK, C., STEFANOVA, I. \& ZIEGLER, S. S. 2009. Woodland-to-forest transition during prolonged drought in Minnesota after ca. AD 1300. Ecology, 90, 2792-2807.

STOCKMARR, J. 1971. Tablets with spores used in absolute pollen analysis. Pollen et Spores, $13,615-621$.

TITUS, J. E. \& SULLIVAN, P. G. 2001. Heterophylly in the yellow waterlily, Nuphar variegata (Nymphaeaceae): Effects of [CO2] natural sediment type, and water depth. American Journal of Botany, 88, 1469-1478.

TSCHIRCH, A. 1889. Angewandte Pflanzenanatomie, Wien \& Leipzig, Urban \& Schwarzenberg.

WARNER, B. G. 1984. Late Quaternary paleoecology of eastern Graham Island, Queen Charlotte Islands, British Columbia, Canada. Ph.D., Simon Fraser University. 
WARNER, B. G. 1989. Methods in Quaternary Ecology .10. Other Fossils. Geoscience Canada, $16,231-242$.

WILLARD, D. A., BERNHARDT, C. E., WEIMER, L., COOPER, S. R., GAMEZ, D. \& JENSEN, J. 2004. Atlas of Pollen and Spores of the Florida Everglades. Palynology, 28, $175-227$. 


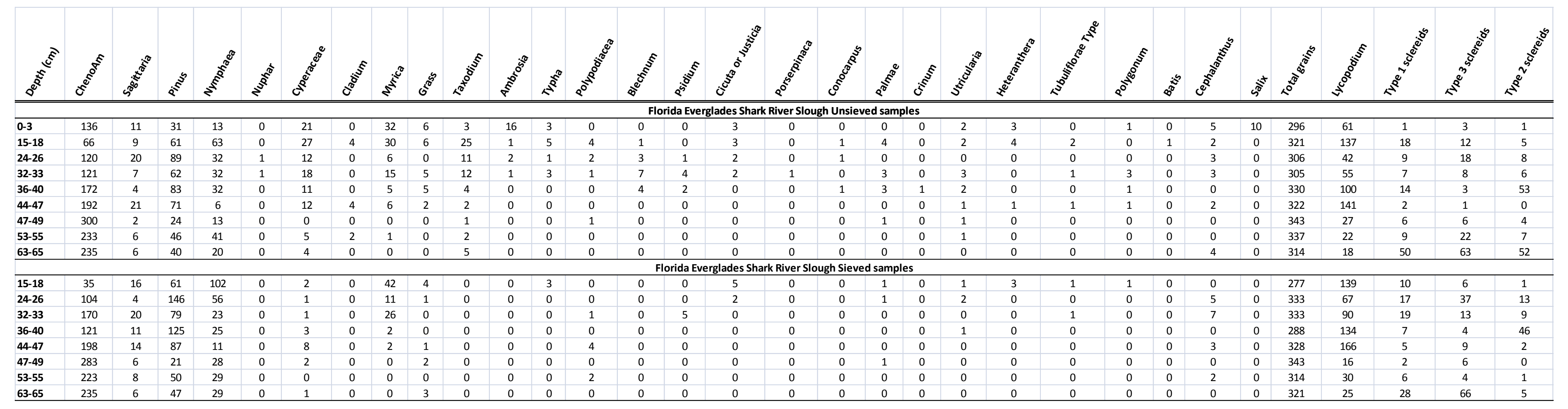

